\title{
Wstęp
}

\section{Trauma kulturowa jako palimpsest: (post)komunizm w kontekście porównawczym nowoczesności, totalitaryzmów i (post)kolonializmów}

\begin{abstract}
Wtedy śmierć stała się człowiekiem, który zabije mnie na zlecenie. Bardzo młodym, niepozornym mężczyzną. ... artystą życia, który przedtem pije kieliszek wódki, potem kupuje na targu torebkę czereśni dla siebie, żony i dziecka. ... kupowałam sobie czereśnie przeciwko jego czereśniom. ... Rywalizacja czereśni skończyła się dziesięć lat temu. ... Jednak jedzenie czereśni na zapas wkradło się we mnie tak głęboko, ze nie mogę się go pozbyć.
\end{abstract}

Herta Müller, Nadal ten sam śnieg i nadal ten sam wujek

* Adres do korespondencji: Instytut Filologii Angielskiej, ul. Kuźnicza 22, 50-138 Wrocław; Instytut Filologii Słowiańskiej, ul. Pocztowa 9, 53-313 Wrocław. E-mail: dorota.kolodziejczyk@uwr. edu.pl; mateusz.swietlicki@uwr.edu.pl.

Adres do korespondencji: Facultatea de Limbi şi Literaturi Străine, Str. Edgar Quinet 5-7 Sector 1, 70106, Bukareszt, Rumunia. E-mail: stefbogdan@gmail.com. 
Herta Müller w swej autobiograficznej prozie wspomina strach przed groźbami unicestwienia ze strony rumuńskiego państwa. Jedzenie czereśni staje się dla niej sposobem radzenia sobie ze strachem, taktyką, którą wypracowała niemal nieświadomie, próbą podjęcia pewnego rodzaju działania odstraszającego, mającego wiele wspólnego ze sposobem, jaki autorka stosowała jako dziecko, by zjednoczyć się z naturą. Podstawą zarówno dziecięcych, jak i dorosłych strategii radzenia sobie ze strachem jest pragnienie metamorfozy uwalniającej od poczucia wyobcowania tak namacalnego jak „samo ciało” (Moja ojczyzna była pestka jabłka). Dziecko jedzące rośliny, by przekształcić się w nie i stać się jednym z potężną naturą, wyrasta na dorosłą uwięzioną w totalitarnym państwie, jedzącą czereśnie przeciwko czereśniom funkcjonariusza Securitate mającego ją zlikwidować. Strukturalnie i emocjonalnie są to podobne strategie zakorzenione w dziecięcym magicznym myśleniu, które dąży do uzyskania poczucia sprawczości i „ja”. Zastępowanie rzeczywistości pozbawionej niezbędnych fundamentów życia jest głównym celem rytuału uruchamiającego magię, której psychoanaliza nadała nazwę narcyzmu dziecięcego. Jest to narcyzm szczególnego rodzaju: nie obiecuje wyobrażeniowej wszechmocy, zakłada jedynie, a może aż, przetrwanie, a jego funkcją jest dosłownie wytrwanie w czasie (Nadal ten sam śnieg i nadal ten sam wujek).

Opisy traumatycznego doświadczenia państwa totalitarnego w prozie Herty Müller są unwiersalnym przykładem myślenia o traumach społeczeństw po II wojnie światowej w bloku wschodnim. W jej twórczości czytelnik odnajduje cały wachlarz typowych dla traumy objawów, jeśli cokolwiek w wypadku traumy jest typowe: wszechobecne milczenie; aurę niewypowiedzianej tajemnicy otaczającej rodzinę i wyczuwaną przez dzieci, które jako dorośli zaczynają rozumieć, lecz tylko przez nieodłączną pamięć zagadkowego strachu; przedmioty, które są świadkami niewypowiedzianych wydarzeń z przeszłości; groźby ze strony państwa, których niesamowita bliskość naprowadza na wspomnienia o nieopowiedzianych historiach z dzieciństwa i sugeruje, że postpamięć jest przenoszona nie tyle w słowach, ile w ciele, w doznaniu strachu i przekonaniu o własnej bezradności w rękach potężnego państwa; i, w końcu, status mniejszości, której w nacjonalistycznym komunizmie przypada rola kozła ofiarnego i która dodatkowo pogłębia poczucie bezradności jednostki w uścisku kontrolującego państwa.

Jednakże to kompulsywne, powtarzające się zachowania, o których pisze Herta Müller, stanowią rdzeń traum wywołanych przez państwo komunistyczne. Opowiadając o ciągłych pracach domowych wykonywanych przez matkę, zwłaszcza o sprzątaniu, Müller zastanawia się, czy nie jest to skutek przebywania matki w radzieckim obozie pracy przez pięć lat po II wojnie światowej:

Dla mojej matki praca była czymś mechanicznym, leżała w jej naturze. Matka nie męczyła się, pracując, była zarówno całkowicie nieobecna, jak i w pełni obecna. Ponieważ była nieobecna dla siebie, stawała się tym, co robiła rękami. Znikała jako osoba i stawała się motoryczna, proces w sukience i fartuchu (Moja ojczyzna była pestka jabłka). 
Po latach, kiedy Herta Müller krótko pracuje jako nauczycielka przedszkolna, znów mierzy się z zagadką powtórzenia, które może być powrotem do wypartej traumy, a być może też sposobem na wyeliminowanie jej ze śladów pamięci, a nawet na pokonanie rdzenia traumy, samego bólu. Dzieci w przedszkolu obawiają się bicia, które, jak wspomina Müller, okazuje się główną metodą wychowawczą w tej instytucji, i jednocześnie o nie proszą. Ich repertuar komunikacyjny ogranicza się do reaktywnej siły bicia: „Pogardzały mną, ponieważ ich nie biłam, żądały bicia, jakby było darem, łaską. Nie reagowały na słowa ani krzyk". (Moja ojczyzna była pestka jabłka. Müller widzi w tym miniaturową replikę państwa totalitarnego, a zarazem jego idealnie logiczną konsekwencję: „Myślę, że wszystko się ze sobą łączyło, bez obrazu człowieka z betonu i dłąwiącej wszystko ideologii nie byłoby kijów w przedszkolu" (Moja ojczyzna była pestka jabłka.

Cathy Caruth w swej interpretacji teorii traumy Freuda proponuje ponowne odczytanie przymusu powtarzania, stanowiącego podstawę tej teorii traumy, i zauważa, że nie jest to narracja powrotu i przezwyciężenia, w którą dziecko z badań Freuda angażuje się w zabawie fort und $d a$, lecz wykreowanie nowego języka „poza

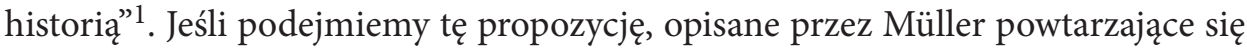
zachowania są nie tyle sposobami na przepracowanie traumy poprzez jej ponowne przeżywanie, ile raczej sposobami likwidowania pamięci swojej obecności w wydarzeniu, które mogło być śmiertelne. Kompulsywne powtórzenia są tą samą kategorią działań odstraszających, jak jedzenie roślin w dzieciństwie lub czereśni w wieku dorosłym - wstrzymywaniem „ja” przez zawieszanie czasu, aby wytrwać.

Obsesyjno-kompulsywne zachowania, takie jak niestrudzona praca mieszkańców wioski, a zwłaszcza nieustanne sprzątanie matki, i - przez analogię - powtarzające się absurdy totalitarnego państwa, w którym stanie w kolejce po zapas mleka lub chleba jest równie dobrze konieczną walką z wywołanym przez państwo głodem, jak i powtarzającą się traumą braku kontroli nad nawet najbardziej podstawowymi środkami do życia, czynią koniecznym postawienie pytań o pamięć, pamiętanie, odtwarzanie w narracji i rozumienie sensu. Krótko mówiąc, badacz traumy musi się skonfrontować z perswazyjnym aspektem narracji traumatycznej, zazwyczaj niedoskonałej, pełnej luk, zaniechań, być może nawet fałszywych wspomnień, nieokreślonych sygnałów i wszelkiego rodzaju strategii unikowych. Przede wszystkim jednak musi zmierzyć się z najbardziej dotkliwym skutkiem traumy, który nie jest nawet pamięcią doświadczonego bólu, lecz groźbą zaniku pamięci jako jedynego śladu tego, co wydarzyło się w przeszłości, a wraz z nią tego, co składa się na ludzkie „ja" - o pamiętaniu jako połączonym efekcie emocji i społecznej więzi słów. Jest to zagrożenie całkowitą ciszą i pustką, które są następstwem traumy: „Myślę, że w tej wsi wszędzie było coś choć trochę sfałszowanego. To, co stało jak zawsze, jak jej przygnębiająco puste trzysta lat, w rzeczywistości dawno już zostało przewrócone do góry nogami przez katastrofy historii” (Moja ojczyzna była pestka jabłka).

${ }^{1}$ C. Caruth, Parting Words: Trauma, silence and survival, „Cultural Values” 5, 2001. 
Dyskusja o traumie została odczytana przez niektórych krytyków jako rezultat przekształcenia rzeczywistej treści („rzeczywistości”, która spowodowała traumę) poprzez ukrycie, wyparcie, kondensację, wyeliminowanie. Bardzo podobnie jak Traumarbeit, termin zaproponowany przez Freuda, lub jak estetyczne procedury stylizacji i literaturyzacji ${ }^{2}$. Takie krytyczne poglądy sugerują, że zapisywanie traumatycznych zdarzeń zaczyna się od oryginalnej prawdy, która jest następnie zakodowana i komunikowana w bardziej lub mniej wymyślony sposób. Jest to spójne zarówno ze starożytną tradycją retoryczną, zgodnie z którą styl oratora ma na celu mistrzowsko ubrać faktyczne lub ideowe ciało, oraz w modelu psychoanalitycznym, w którym zawartość „,utajona” zostaje przekształcona w „jawną” reprezentację (Freud) lub „Realne” w „Symboliczne” (Lacan). Zgodnie z tym modelem trauma jest nawarstwionym palimpsestem, a od interpretatora oczekuje się, że wykona procedurę zbliżoną do terapeutycznego anamnesis, która pozwoli odsłonić ową mylną powłokę i przedostać się przez wierzchnią warstwę.

Z perspektywy postmodernistycznej, która identyfikuje się z alternatywną tradycją retoryczną uznającą, że idea i forma słowna są nierozłączne, nie da się wyprowadzić rzekomo empirycznej rzeczywistości traumy z jej nieodłącznie dyskursywnego, a tym samym subiektywnego, kontekstu. Traumatyczna treść jest postrzegana, selekcjonowana i oceniana jako taka przez świadomość ofiar/świadków dokładnie dlatego, że jest straszna i zadaje rany ich podmiotowości. Rzeczywistość jest rejestrowana jako trauma, a trauma jest jedyną rzeczywistością dla cierpiącego podmiotu. Albo, jak twierdzi badaczka feminizmu Leigh Gilmore: „bez języka doświadczenie jest niczym"3. W przeciwieństwie do stratyfikowanego modelu palimpsestu, tego rodzaju rozumienie dyskursu traumatycznego zakłada, że nasze traumatyczne doświadczenia (re)prezentują się naszej subiektywności jako zawsze już przełożone na wersję dyskursywną. W związku z tym trop palimpsestu zmienia się z metafory w paradoks: trauma nie jest już zbiorem nakładających się na siebie warstw, lecz ko planarnym palimpsestem, w którym obiektywne fakty i ich subiektywne zapisy występują na tym samym poziomie dyskursywnym, w podobnej relacji jak oryginał i tłumaczenie są koplanarne dla Waltera Benjamina (Die Aufgabe des Übersetzers). Trauma jest jednocześnie represją i (re)prezentacją (tj. obrazowaniem i powrotem) destrukcyjnego doświadczenia (,jednoczesność traumy i auto-reprezentacji”" ${ }^{\text {). Na- }}$ zwijmy to Traumaarbeit, czyli dyskursywnym procesem, w którym traumatyczne „fakty” zależą od subiektywnych (re)prezentacji. Traumaarbeit składa się z sym-

${ }^{2}$ W przeciwieństwie do bardziej poważnych „świadectw” prostych ludzi, większość rumuńskich komunistycznych wspomnień o aresztach inteligencji odbierana jest jako mniej wiarygodna i prawdziwa, w związku z zarzutem o proces literaturyzacji. Pogląd ten reprezentują nie tylko literaturoznawcy, tacy jak Adrian Marino (który sam był więźniem reżimu) i Ruxandra Cesereanu, lecz także wielu autorów dzienników, takich jak psycholog Nicolae Mărgineanu, dziennikarz Gabriel Bălănescu, dyplomata Constantin Cesianu, pisarz i polityk Ioan Victor Pica czy historyk Constantin C. Giurescu.

${ }^{3}$ L. Gilmore, The Limits of Autobiography: Trauma and Testimony, Ithaca 2001, s. 6.

${ }^{4}$ Ibidem, s. 3. 
bolicznych (trans)formacji, które równocześnie pokazują i kamuflują przyczynę, przedmiot i naturę cierpienia ofiary. Rzeczywiste cierpienie jest wpisane od samego początku w swoją transformacyjną wersję, a obie prezentują się naszemu rozumieniu jako dwa różne zjawiska połączone w jeden i ten sam anamorficzny obraz. Podobne koplanarne istnienie można przypisać indywidualnym i zbiorowym lub wcześniejszym i aktualnym traumom, tragediom przedkomunistycznym i komunistycznym, lub, jak stwierdziła Marianne Hirsch, pamięci z pierwszej ręki i "postpamięci«, a także historycznej ciągłości, lecz również i lukom, które tę ciągłość zrywają

Trauma zadana społeczeństwom Europy Środkowej, Wschodniej i Południowo-Wschodniej przez totalitaryzm, jak również posttraumatyczne symptomy, obecne w niemal każdym obszarze dyskursu publicznego, to kwestie, których niedostateczne rozpoznanie stanowi dotkliwy brak w przestrzeni krytycznej kultur regionu.

Zarówno totalitarna trauma, jak i (post)traumatyczny okres przejściowy w krajach Europy Środkowej, Wschodniej i Południowo-Wschodniej przybierały wiele form. Chociaż ocena totalitarnej przeszłości była już przedmiotem licznych dyskusji, niejednokrotnie miały one charakter stronniczy lub pogłębiały podziały, a traumatyczne dziedzictwo do dziś nie zostało w pełni historycznie, społecznie czy też kulturowo przepracowane. Co więcej, debaty te nierzadko same w sobie były objawami stanów posttraumatycznych.

Teksty zawarte w niniejszym tomie poświęcono rozważaniom nad traumą we współczesnej historii państw Europy Środkowej, Wschodniej i Południowo-Wschodniej oraz interakcji między historycznym i doświadczanym palimpsestem zaburzeń kulturowych. Posługując się interdyscyplinarnymi i transdyscyplinarnymi metodologiami, wykorzystując badania nad traumą, (post)pamięcią, okresem przejściowym, postkomunizmem, jak również postkolonializm, ich autorzy zbadali traumę, ukazując jej złożony kontekst historyczny — podejmując takie kwestie, jak Ukraińska Powstańcza Armia z perspektywy polskiej i ukraińskiej, masowe repatriacje powojenne czy przesiedlenia i wydalenia lokalnej ludności $z$ odmiennych grup etnicznych $\mathrm{w}$ imieniu jednolitego państwa, oraz kulturowy — odszyfrowując języki i dyskursy traumy w teatrze, kinie, sztuce i nowych mediach, oraz literaturoznawczą — skupiając się na geopolityce traumy, narracjach pamięci i postpamięci, widmowych powrotach przeszłości w międzypokoleniowym przekazie, często podejmując tematy w przestrzeni polityczno-społecznej okresu reżimu komunistycznego zabronione/zmanipulowane.

${ }^{5}$ M. Hirsch, The Generation of Postmemory: Writing and Visual Culture After the Holocaust, New York 2012, s. 5 i passim. 


\section{Bibliografia}

Caruth C., Parting Words: Trauma, silence and survival, „Cultural Values” 5, 2001.

Gilmore L., The Limits of Autobiography: Trauma and Testimony, Cornell University Press, Ithaca 2001.

Hirsch M., The Generation of Postmemory: Writing and Visual Culture After the Holocaust, Columbia University Press, New York 2012.

Müller H., Moja ojczyzna była pestka jabłka, tłum. K. Leszczyńska, Wydawnictwo Czarne, Wołowiec 2016.

Müller H., Nadal ten sam śnieg i nadal ten sam wujek, tłum. K. Leszczyńska, Wydawnictwo Czarne, Wołowiec 2014. 